\title{
2
}

\section{Conceptualizing and Analyzing Family Policy and How It Is Changing}

\author{
Mary Daly
}

This contribution provides a conceptually based analysis of family policy in Europe, identifying the defining constituent elements as well as the main changes underway. The three questions that underlie the chapter are: What constitutes family policy? How is it changing? And how should we conceive of and study family policy going forward? To address these, we need a clear conception of family on the one hand and the relevant policies on the other. A core aim of the chapter is to set out an analytic framework which identifies the interrelationships, functions, policy constituents, and trends in family policy. Toward this end, the chapter is organized into two main parts. The first part focuses on the conceptualization of family policy. It proceeds by first drawing from the existing literature and second reviewing briefly both the historical evolution and particular models that have prevailed historically in Europe. The second part of the chapter identifies major contemporary trends, focusing on three main areas of family policy: income supports for families with children, early childhood education and care (ECEC), and parentingrelated leaves from employment. As well as setting out the detail, this section also considers the significance of these changes in terms of underlying large shifts and changing conceptualizations of family policy. In the final section I set out some considerations for evaluating and theorizing family policy going forward. The chapter is informed throughout by a comparative sensibility,

M. Daly (凶)

University of Oxford, Oxford, UK

e-mail: mary.daly@spi.ox.ac.uk 
mainly from a perspective of the European Union (EU) countries. An overarching line of interrogation and intellectual challenge for the field of family policy analysis as a whole is to move beyond a quite particularistic and narrow orientation which characterizes the field.

\section{Conceptualizing the Field of Family Policy}

\section{Insights from Existing Literature}

In terms of focus and conceptualization, research and scholarship to date have concentrated mainly on identifying the different dimensions and areas of family policy, strongly favoring analysis of institutional features and underlying exigencies, especially in terms of the "problems" policy is intended to ameliorate and hence its functions (Ferrarini, 2006; Hantrais, 2004; Kaufmann, 2002; Wennemo, 1994). This literature has shown that the policy field is potentially quite broad and that a varied set of measures has been developed for the purposes of supporting families and regulating family life. These include cash transfers, tax credits and tax allowances, employment leaves, child-related education and care services, family services, employment leave arrangements, and legal measures to encode rights and responsibilities (Fox Harding, 1996; Millar \& Warman, 1996; Saraceno, 2011). The comparative literature-which is a marked characteristic family of policy research-also makes clear that there is great variation in the primacy, role, and constituent elements of family policy cross-nationally (Daly, 2010; Gauthier, 1996; Saraceno \& Keck, 2010).

All of this has a deceptive simplicity to it. In fact, though, there are many complexities to be worked out, especially in a policy field that is developing quite rapidly with policymakers appearing to be more and more prioritizing the family as a focus of policy development and intervention.

The definition and scope of family policy is not clear-cut and there is no consensus about either. Gauthier (1999, p. 32) terms family policy a "wide umbrella of policies." As such, some serious decisions are required about what to include and exclude. These decisions cohere around four main sets of questions. The first is where to draw the boundary around family policy in the policy universe overall: which areas and measures should be included or excluded? The most widespread consensus in scholarship is to define family policy as policies associated with families with children. But what about other domains that touch on matters of private and family life? Care for older people is a prime example (this point is further developed in Chapter 14 
by Dykstra \& Djundeva in this volume). Why might this be seen as family policy? One possible reason is that it falls within the role of and set of responsibilities assigned to family membership and the family as a social institution. However, while true historically in some European countries, this is less and less the case now, especially legally_only in three European Union (EU) member states do families have a legally enshrined responsibility to care or provide for their elderly relatives (Hungary, Latvia, \& Lithuania) (Spasova et al., 2018). Hence, on this count anyway, it seems appropriate to adopt a narrower definition of family policy-as centered around the well-being, functioning, and responsibilities of families with children. ${ }^{1}$ Employment is another example. One could argue for an inclusive approach here along the lines that family and other policies are concerned with employment or affect employment-related behavior by virtue of the incentives and disincentives that are built into them, especially regarding the behaviors of parents and spouses. However, that said, family policy is not employment policy and its primary purpose arguably lies elsewhere (to financially secure the family as institution, for example, or to monitor and support child-rearing). There is an insight here about what is directly targeted by policy as against looser interconnections, which I will follow up below. The point to note now is that it calls on the analyst to be mindful that there are broader and narrower perspectives on what it is that family policy may aim to do and that family policy is always part of a wider social policy constellation.

A second and related issue pertains to the level(s) of analysis and in particular what attention to give to the vertical (as against horizontal) dimensions. The tradition in the field is for analysis situated at a single dimension or level, usually the nation state level. This closely reflects the policy world, with family policymaking centralized at nation-state level, especially in terms of cash transfers. It is a view biased by viewing family policy as cash transfers though; when one brings family services into the analysis other levels come into play. As this handbook testifies, family policies are formulated and implemented at other levels also. In addition to the nation-state level, such other levels include supranational organizations such as the United Nations (UN), the Organization for Economic Cooperation and Development (OECD) and the EU, the subnational level of municipalities, states, or regions in which people live, and the organizations in which people work (companies or firms). Each of these has an analytical purchase. However, in the European context, it should be pointed out that the EU has no direct competence in family policy_that is a member state jurisdiction. This notwithstanding, the EU has

\footnotetext{
${ }^{1}$ It should be noted, though, that some of the care literature includes both care for adults and that for children within the same framework (e.g., Saraceno \& Keck, 2010).
} 
taken action in matters that are closely related to family functioning, workfamily balance, for example. The significance of this is that the transnational level should be part of any theoretical framework on family policy. So too should the possibility of decentralization within the nation-state. Elements of family policy are frequently administered at a subnational level, especially family-related services (such as ECEC). Companies or firms too are potential family policy actors, most often by virtue of their provision of services (again with ECEC as the prime example but also-and especially in the past-income supplementation to male workers with family responsibilities).

Thirdly, review of the literature also raises a question about whether to adopt what is officially defined or conceived as family policy, or to go outside or beyond states' self-representations of what constitutes family policy. The latter allows the analyst to take a more theoretically informed and even critical approach. Kamerman and Kahn $(1978$, p. 3) bring this issue to the fore when they differentiate between explicit and implicit family policy. To qualify as explicit, policies and programs are put in place to achieve explicit goals regarding the family and the situation of families; implicit family policy is where governmental actions and policies may not be specifically or primarily addressed to the family but which have indirect effects on the situation of families and the well-being of the individuals who comprise them. In the former, family has to be a specific policy focus to merit the label "family policy." There is a deliberateness about it with intentionality as a key factor driving policy. An explicit family policy could not exist without a strong sense of the family as a unit or institution of importance in society. This in turn rests upon acceptance of the state as a legitimate actor in regard to the family. The core meaning of "implicit," on the other hand, is that the family as such is not targeted but is envisaged to be affected by policies nonetheless. In the implicit scenario, family policy is not a recognizable policy entity, resembling more a "perspective" than a "field" in Kamerman and Kahn's terms. It seems to me that-given that family policy is a recognizable field within and across the European and other countries now (unlike when Kamerman and Kahn were writing 40 years ago) - an explicit understanding of family policy provides a rich field of analysis.

However, it is not as easy as that for we need to update what an explicit policy approach might mean nowadays. In this, we cannot regard policy as fixed or follow blindly what states or other entities consider as "family policy." The risk with the latter is that we miss relevant aspects of policy and also that the broader impact and focus will slip from view. Hence, as well as a sensitivity to explicit or implicit family policy, our understanding needs to be 
centrally informed by a conception of family ${ }^{2}$ (what it is and what it does). The existing literature suggests that a complex understanding would differentiate between family as a set of individuals and as a collective structure (Mätzke \& Ostner, 2010). In the former, emphasis is placed on family as a set of roles and relationships; the latter emphasizes the functions performed by the family as a structure or mode of organization. The former is more novel than the latter as a line of analysis in family policy. The need to disaggregate family to focus on the individuals who comprise it comes especially from the feminist literature which has sought to move beyond the conception of family as a unit(y) of common interests among members to highlight internal processes, often associated with power imbalances between family members, that have an impact (Williams, 2004). Disaggregation is important also from a generational perspective, especially from a child-centered vantage point (Daly, 2020a). While there are limits to the extent to which this chapter can take account empirically of the degree to which family policy instruments affect individual family members, for the purposes of a theoretical framework it is important to note that it can and does seek to influence individual family relationships. The following section will demonstrate some such effects.

\section{Insights from Contextualizing Family Policy}

Family policy in Europe has a rich history (Bahle, 2008; Therborn, 2004). There is much to learn from it in terms of not just insights about practice but also from a more theoretical perspective. I undertake a brief historical overview-focusing on the policy modalities as well as variations-in order to develop insights for a theoretical perspective.

It is generally agreed that state responsibility for families developed later than other areas of social policy, especially in comparison to social policies oriented to income redistribution and securing the adult life course (Gauthier, 1996). But we need to temper this interpretation somewhat by recognizing the broader origins of family policy and the philosophical underpinnings involved. The deep roots of family policy lie especially in the institutional and legal context and how the institutions governing family life-like marriage, parenthood, and childhood-have been and are legally constituted (see Hank \& Steinbach, 2019, for a recent overview). These are very long-standing. Thinking about them brings two insights to the fore. First, the legal institutions form the backdrop or underpinning to family policy and highlight an

\footnotetext{
${ }^{2}$ Note that when I say family I mean "families" in recognition of the diversity of families. For this reason also I try to avoid the use of the term "the family."
} 
early intentionality on the part of the state associated with the regulation of the family. Second, they underline a long-standing concern with the family as a structure or mode of organization.

The interest in family as a form of organization gave rise to a number of family policy. One was cash or financial supports through taxation or vouchers which have been very dominant in the field of family policy. Among the first family policies were those offering financial assistance to families mainly in the form of income supplements for children (most widely known as "family benefits" or "child benefits"). These dated from the 1940s in many countries (and earlier in some) (Gauthier, 1996). They varied in terms of whether they compensated for all children and the degree to which they differentiated the level of support on the basis of the child's age or number of children in the family (universal or selective). Eliminating poverty and hardship among families was a widespread motivation for the introduction of child-related financial transfers. This trained the spotlight initially on the most needy sectors of society and so the first such transfers, introduced between the 1870s and 1920s, were directed at special categories of families, typically necessitous mothers, widows, and orphans. There was also a second route to the growth of financial transfers to families-employers adding subventions to wages for the fathers among their workforce. This too was selective in that only some employers engaged in the practice and it took hold only in some countries (principally Austria, Belgium, France, Germany, Italy, Netherlands, and Spain). It underlines the point made earlier about the firm as a potentially important level of family policy implementation. Over time though, national states took on the practice of supporting workers and others with the costs of raising children, either by paying civil servants with children additional wages or allowances or by introducing child benefits and/or tax allowances more universally for families with children. The interest in the family as a particular form of organization was to be seen especially in the channeling of support to fathers, which served to underpin the male breadwinner model of employed father and stay-at-home mother-the industrious father and the caring mother at home symbolizing the appropriate moral order. With the male breadwinner family as the preferred form, early social and family policies linked closely to the idea of a family wage, and provided subsidies for both marriage and the "dependants" of the breadwinner (Crouch, 1999). This, together with the widespread belief that young children should be cared for at home, made for a strong gender division of responsibilities and roles. This helps to explain cross-national and other variations in the degree to which income supports were favored over services. Countries which limited their family policy to income supports tended to 
support a traditional family model whereas those that offered both income and services were less doctrinaire about the best type of family model (true especially of the Nordic countries and France).

Family policy has also been concerned about protecting family-related actors and activities. Protection for mothers has been key here and also has deep roots in family policy. One of the primary policy modalities here has been income and employment protection for new mothers. Maternity benefits are the familiar policy here-combining income subsidies with employment leave for mothers while they are out of employment for childbirth. This is one of the oldest social security benefits in Europe and elsewhere, predating child income support or family income support in many locations. This is a domain of policy that has grown and expanded considerably beyond its roots (as we will see in the next section of the chapter especially). The last two to three decades have seen a notable trend to extend a range of child- and family-related employment leaves to include first parental and later paternity leaves.

It will be obvious that this goes beyond the family as a structure or mode of organization-targeting the roles and behaviors of family members. This is a counterpole (although not necessarily an oppositional one) to the focus on family as structure or institution. In some countries-such as those in the Nordic region where family is not a strong mobilizing concept-familyrelated policy sought to or was utilized to support employment and equal opportunities on the part of both female and male parents. In order to achieve this families were given access to high-quality childcare and other services as well as ensuring income sufficiency. This model did not operate with a strong or uniform concept of family as a collective or even separate institution but was more focused on individual well-being, opportunity, and equality (Ellingsaeter \& Leira, 2006). Women's role and identity as workers was written into the institutions of state and market. Furthermore, while family membership might be a source of emotional stability and identity, family as a privileged social unit was much less supported as compared with other parts of Europe. Service provision for families was widespread and access tended to be anchored in social rights.

The foregoing highlights that the underlying model of family was very important historically in influencing the content and orientation of family policy. Looking at developments in context, further, draws attention on the one hand to social policy's interest in the family as a structure-as an organizational unit and a social institution-and on the other hand to family as comprising relationships, roles, and sets of responsibilities among people bound together by ties of kinship. The underlying point here is that family 
policy modalities potentially affect both. Income supports, for example, if given to the father perpetuate a traditional division of resources whereas if given to the mother allow for some financial independence and autonomous recognition of her role-hence policy (whether it intends to or not) affects the relationships between parents and respective roles and activities in regard to family life. All of this leads me to suggest that family policies serve two main functions: supporting/resourcing individuals/the collective unit and regulating family-related behavior and relationships. Hence, it is vital not to adopt a perspective that limits particular policy instruments to particular functions or orientations (a reason why we need to have a more critical perspective on explicit family policies). I will keep these differentiations and the many complexities to the fore as we proceed.

\section{Recent Changes $^{3}$}

Family policy in most countries has mainly concerned itself with supporting families with income and giving help with child-rearing. Raising children incurs both direct and indirect costs, the former arising from the additional costs involved and the latter mainly from income foregone from employment because of child-bearing and parenting. Welfare state and other policy actors have long compensated for the former but they have been much slower to take on the latter, although moves toward gender equality and work-family balance do contribute to reducing indirect costs. What is happening in each of the three main spheres of family policy today?

\section{Child Income Supports}

As mentioned, historically across Europe child benefits or family allowances were the main pillar of family policy. Designed to assist families with some of the costs of raising children, they date mainly from the period around World War II. Before 1960 child income support was mainly provided through employment-based child supplements to wages (usually paid to fathers), especially in continental European countries, i.e., Austria, Belgium, France, Italy, Netherlands, and Switzerland. Once the system of public support started to be established more extensively, child-related income supports represented a truly innovative form of social right since they tended to have no conditions attached to receipt (Montanari, 2000, p. 309). Usually paid until the

\footnotetext{
${ }^{3}$ This section draws from Daly (2020a) and Daly and Ferragina (2018).
} 
child reaches school-leaving age, some variant of these allowances exists in almost every country of the EU today, although their levels vary considerably and they are not universally available to all families. Means-testing of these allowances tends to be characteristic of the Mediterranean and post-socialist countries although the UK under Conservative leadership also introduced means-testing of the benefit by family income in 2010 (thereby undoing a considerable history of universalism in these benefits). When countries target this type of support, they tend to do so usually on the basis of income, although some countries also target by the age of the child and the number of children (often wishing to support larger families and hence encourage higher fertility). Child benefits are usually funded from general taxation revenues and in this and other ways are an expression of solidarity with people who are raising children (and therefore oriented to horizontal equity).

Looking at the last 20 years or so, there are a number of significant changes to report. While the long-term trend-that is over the 50 years from the 1970 s - is for greater generosity in child income support (Daly \& Ferragina, 2018), the most recent period (since the recession that set in in 2008) has seen reducing generosity in a number of countries (European Commission, 2017). In the EU, 12 member states (mainly Eastern European and Mediterranean countries) made major cutbacks and, between 2008 and 2012, spending on child and family income support fell in 21 out of 28 member states. The cutbacks are instituting significant reforms. Two trends are of particular note.

The first is greater use of targeting. This follows a strongly categorical logic and spells a change in regard to which families with children are prioritized for state support. There are strong moves in some countries (e.g., Greece, Poland, Portugal, Romania) to target support toward larger families or those on low incomes. A focus on financial need is spearheading this move away from universalism and a form of egalitarianism that includes all families. The policy thrust is a move away from supporting families regardless of size, that is away from more generic family support (Eurofound, 2015; European Commission, 2017). A second trend is toward fiscalization of financial support to families (Ferrarini, Nelson, \& Höög, 2012). OECD data suggests that the average value of financial support to families through the tax system now rivals that given to families through the benefit system. ${ }^{4}$ While this approach-effected through tax credits and tax allowances for example-was and still is especially favored by the liberal-oriented countries, it is increasingly found also in other parts of Europe (e.g., Austria, Belgium, Germany, and Italy). As a move away from cash support it portends a change

\footnotetext{
${ }^{4}$ See the OECD family database at: http://www.oecd.org/els/soc/PF1_1_Public_spending_on_family_ benefits.pdf.
} 
in both the form and conditions under which families with children are supported financially and is at its core an attempt to more closely link child and family income support with parental earnings and employment. The behavior of individual family members becomes more important as do the links between family policy and employment. Through these moves, family as an institution is still supported but it is family as an economic unit of gainfully employed individuals that is targeted.

\section{Early Childhood Education and Care (ECEC)}

This type of provision has become much more important over time, associated with a mix of push factors. These include the growth of children's rights, countries' elevated concern with the educational performance and general behavior and achievements of their young populations (especially linked to the perspective of social investment, e.g. Hemerijck, 2015) and also policy's interest in greater gender equality. The provision of daycare and education for children is the classic policy response here. However, looking across countries and periods of time, this is not a uniform provision in that some countries viewed it as care for children whereas others saw it more in terms of education and early learning (see also Vandenbroeck in this volume). Taking a historical look at Europe as a whole, minimal ECEC provision existed until after World War II at which point the national and local authorities started to assume a responsibility to provide ECEC (Moss, 2006; Scheiwe \& Willekens, 2009). From the 1960s to 1970s on, and especially in the last two decades, what was a stream has become a major arterial flow. Here we see the full range of policy actors or levels—-transnational, national, local/municipal, and employer-at play.

In terms of changes and transitions, three general trends are noteworthy. First, there has been a general move in the direction of the educational model. Moss (2006) suggests that this took place in two waves: the 1970s and the last decade or so. The Nordic countries were to the fore in the first wave. While ECEC in Scandinavia has its roots in the care or welfare paradigm, these countries led the way from the 1970s on in moving toward universal ECEC provision that is strongly pedagogical in orientation. An educational modelepitomized in ECEC as the term now used to describe the field-is becoming much more the norm as countries move away from the notion of services as caring for children and toward educating them and developing their abilities at the earliest opportunity. Second, one of Europe's strongest trends in recent years has been a growth in out-of-home ECEC for very young children (up to age three) (European Commission, 2013). Here cross-national 
agencies have been very important. In Europe this has been led by the strong stance taken by the EU in the Barcelona targets set in 2002 which aimed for $33 \%$ of the zero-two-year-old cohort and $90 \%$ of those aged between three and six years in ECEC by 2010 (ibid.). The OECD has also been a leader, its message generally dovetailing with that of the EU (Mahon, 2010). A third, related, trend is a growth of guarantees to ECEC for children. While such guarantees are often rhetorical or abstract, some seven EU member countries now guarantee a legal right to ECEC for each child under two years, often immediately after the end of parental childcare leave (Eurydice, 2019). These are Denmark, Estonia, Finland, Germany, Latvia, Slovenia, and Sweden. In most of these countries, the entitlement usually implies a full-time place. Other countries start the guarantee later. In Belgium, France, Luxembourg, Hungary, Malta, Spain, and the UK, a place in publicly subsidized ECEC is guaranteed from the age of three or a little earlier. So, over half the EU member states grant children a right to ECEC. Fourthly, it is important to note that the trend toward ECEC expansion for young children is not unequivocal as in some places it is accompanied by a choice-oriented introduction of home care allowances (e.g., Finland, France, Norway, Sweden, Germany) (Lohmann, Peter, Rostgaard, \& Spiess, 2009).

Read through the perspective developed earlier we see a move toward a greater focus on the resources available to individuals (especially children) and the shifting of some child-rearing outside the home (although the responsibility remains with parents and the family more generally). The fact that some countries are drawing back from this and have two approaches in playthat is offering services but also giving incentives for children to be cared for at home-underlines some ambivalence and a tussle between making child development a public good as against supporting and buttressing the family as a unit and location for child-rearing.

\section{Parental and Maternal/Paternal Leaves}

Historically, maternity has been the main focus of provisions oriented to parents. This continues to be an important plank of provision but the innovation nowadays is generally elsewhere: in other types of family-related leave. From the 1990s on parental leave has become more important and more widespread, generalized as a norm of modern welfare state provision and endorsed especially by the EU and the OECD. Essentially, there has occurred a two-fold shift in focus: from mothers to parents, and from mothers to fathers. 
Increasingly now, countries offer parental leave which is available to both mother and father. The matter of the division of the leave between the parents and whether to prescribe certain portions of it for the mother or the father, part of a general attempt to increase fathers' uptake of the leave, is an important line of innovation and development in these leaves. The core trend has been for parents being left to themselves to decide how they will utilize and divide the parental leave between them. There is a countertrend though in that sometimes, a certain period is set aside for the parent who is not on leave; an individual, non-transferable right - the so-called "father quotas"was pioneered in Norway to encourage fathers to take child-related leave and has taken firm hold in the other Nordic countries. In addition to maternity and parental leave, most European countries now offer father-specific paternity leave which is job-protected leave provided to the employed father, normally to be taken near the time of childbirth in order for him to spend time with his newborn child and offer support to the mother and any other children in the home. Most widely, it is of short duration-a number of weeks - and paid at a flat-rate. The motivations for its introduction vary but it is at root an attempt to improve gender equality between parents and also to enable the new father to have a bonding period with his newborn.

The situation now is that almost all countries in the EU have three types of such leave available: maternity, parental, and paternity (European Commission, 2017). To summarize a complex set of developments, EU countries have seen moves to consolidate maternity leave, expand parental leave, move to the couple as the unit of entitlement rather than the individual parent(s), and increase the availability of paid leave to fathers (either through extending paternity leave and/or making a portion of the parental leave attractive to fathers) (Blum, Koslowski, \& Moss, 2017). The implications for parents are obvious, those for the construction of childhood and the treatment of children less so. Here, we see a focus on family-related behavior rather than structure through the greater engagement by the state in how children are reared and the respective roles and investments of the two parents. We could read the current policy consensus as assuming that child well-being and a "good childhood" are best secured by: (a) having both parents present in the first month or two, (b) being cared for at home by the mother with some input from the father for about another year, and (c) having access to an increasing volume of out of home ECEC from the age of 1 on. 


\section{Conclusion}

Family policy, at its most developed in Europe among world regions, refers to state policies oriented to the welfare of families with children and the support and regulation of the family as an institution and a way of life. While societies have their own specific histories on how they organize their family policy (and indeed how active and recognized it is as a policy field), the main policy modalities that exist across countries are in the form of cash benefits or tax allowances for families with children (most widely to help them with the costs of rearing children), services oriented to early childhood care and education (committed to a variety of goals, including children's development and education and also support of parental employment) and a series of leaves from employment for child-related reasons (also intended to be multifunctional but especially oriented to the organization of employment and family life of parents).

As this whole chapter has shown, family policy is a dynamic area of policy within and across countries. During the last 20 years or so, not only have governments become more active on family policy but new areas of policy have been added and developed and existing provisions fundamentally reformed. There is a move toward a more diversified set of family supports wherein cash benefits sit alongside tax allowances, services, leaves, and employment-based measures. Again with cross-national variations, it is generally the case that the field is broadening and deepening and services are becoming a larger part of the redistribution toward families. This reflects especially a greater concern with children's early education, development, and well-being. As they have been developed through family policy, concerns around children's development and resources have seen both greater access for (especially young) children to early education services and also targeting of income support on the most deprived families. We might conclude from this that relationships and resource distribution among generations are increasingly foregrounded (Daly, 2020a).

Policy concern with the family as an institution or structure remains strong and is even growing in some countries, although the degree of support for a traditional family form is generally declining and it is now the characteristics of the family as an economic unit (rather than a particular physical structure such as based on marriage) that dominate. Hence, policy continues to reproduce the family, but it does so in somewhat different ways as compared with the past and arguably also more directly. Consider as an example the sense of a greater degree of regulation of child-rearing and the employment-related behaviors of adult family members (Papadopoulos \& Roumpakis, 2019). The 
notion that family policy may now have a more instrumentalist, economic cast-as against resourcing the family as having moral authority (which was true especially in some of the continental European countries in the past)—is also worth considering.

A further trend is a general move to balance or "reconcile" work and family life (Lewis, 2009). This has had two main expressions in policy. On the one hand, employed parents are given increased incentives and support to take time off work to care for their children when they are deemed to need it. Both parents can be targeted in this regard an attempt to affect the share of unpaid work done by each but there is increased interest in encouraging fathers to take (short periods of) time off work to care for their very young children. On the other hand, there is a general move toward activating people to be employed so as to raise the level of gainful activity (and associated sense of responsibility). It will be obvious that there is a certain tension if not contradiction-between the two types of 'reconciliation'. Some have seen a 'feminization' of the male life course (Esping-Andersen, 2016) but to me the father-oriented measures (outside of Scandinavia especially) are too weak to be other than a symbolic policy (Daly, 2020b).

I opened this chapter by considering how to conceptualize family policy and I want to take up that matter again here, in line with the chapter's overall aim of developing a framework for the analysis of family policy in this volume and elsewhere. There are a number of first principles of relevance it seems to me. The first is that the two-fold framework of family as structure/unit and as a collection of individuals has wide application for the analysis of family policy. It is also clear, though, that these rather crude categories need to be more finely calibrated so as to pick up nuance in both policy and its reform. Generally, I tend to agree with Papadopoulos and Roumpakis (2019, p. 249) that we need to move beyond narrow conceptualizations of the family and engage with the family as a collective socio-economic agent. Second, while the policy details are complex, essentially the analysis confirms that it is meaningful to regard family policy as exercising two main functions: resourcing families and regulating them (with both understood as matters of degree). Third, it seems essential to contextualize family policy in a broader societal context, by understanding family as a social institution in which various actors are invested. While we have not examined the agency or implementation of family policy in detail here, the analysis tends to confirm the editors' contention that the agency in family policy development potentially operates at four levels: cross-national, national, subnational, and at the level of the firm or company. 


\section{References}

Bahle, T. (2008). Family policy patterns in the enlarged EU. In J. Alber, T. Fahey, \& C. Saraceno (Eds.), Handbook of quality of life in the enlarged European Union (pp. 100-25). London: Routledge.

Blum, S., Koslowski, A., \& Moss, P. (Eds.). (2017). 13th international review of leave policies and related research 2017. International Network on Leave Policies and Research.

Crouch, C. (1999). Social change in Western Europe. Oxford: Oxford University Press.

Daly, M. (2010) Families versus state and market. In F. G. Castles, S. Leibfried, J. Lewis, H. Obinger, \& S. Pierson (Eds.), The oxford handbook of the welfare state (pp. 139-151). Oxford: Oxford University Press.

Daly, M. (2020a). Children and their rights and entitlements in European welfare states. Journal of Social Policy, 49(2), 343-360.

Daly, M. (2020b). Gender inequality and welfare states in Europe. Cheltenham, UK: Edward Elgar.

Daly, M., \& Ferragina, E. (2018). Family policy in high-income countries: Five decades of development. Journal of European Social Policy, 28(3), 255-270.

Ellingsaeter, A.-L., \& Leira, A. (2006). Politicising parenthood in Scandinavia: Gender relations in welfare states. Bristol, UK: The Policy Press.

Esping-Andersen, G. (2016). Families in the 21st Century. Stockholm, Sweden: SNS Vorlag.

Eurofound. (2015). Families in the economic crisis: Changes in policy measures in the $E U$. Luxembourg: Eurofound.

European Commission. (2013). Barcelona objectives the development of childcare facilities for young children in europe with a view to sustainable and inclusive growth. Luxembourg: European Commission.

European Commission. (2017). Taking stock of the 2013 recommendation on 'Investing in Children: Breaking the Cycle of Disadvantage' (Commission staff Working Document, SWD(2017) 258 final).

Eurydice. (2019). Eurydice brief: Key data on early childhood education and care in Europe. Luxembourg: Publications Office of the European Union.

Ferrarini, T. (2006). Families, states and labour markets: Institutions, causes and consequences of family policy in post-war welfare states. Cheltenham, UK: Edward Elgar.

Ferrarini, T., Nelson, K., \& Höög, H. (2012). The fiscalization of child benefits in OECD countries. (GINI Discussion Paper No.49). Amsterdam: AIOS.

Fox Harding, L. (1996). Family, state and social policy. Basingstoke, UK: Macmillan.

Gauthier, A.-H. (1996). The state and the family: A comparative analysis of family policies in industrialized countries. Oxford: Clarendon Press.

Gauthier, A.-H. (1999). The sources and methods of comparative family policy research. Comparative Social Research, 18(special issue), 31-56. 
Hank, K., \& Steinbach, A. (2019). Families and their institutional contexts: The role of family policies and legal regulations. Kölner Zeitschrift Für Sozialpsychologie, 71(Suppl 1), 375-398.

Hantrais, L. (2004). Family policy matters: Responding to family change in Europe. Bristol, UK: Policy Press.

Hemerijck, A. (2015). The quiet paradigm revolution of social investment. Social Politics, 22(1), 242-256.

Kamerman, S., \& Kahn, A. J. (1978). Family policy: Government and families in fourteen countries. New York: Columbia University Press.

Kaufmann, F.-X. (2002). Politics and policies towards the family in Europe: A framework and an enquiry into their differences and convergences. In F.-X. Kaufmann, A. Kuijsten, H.-J. Schulze, \& H.-J. Strohmeier (Eds.), Family life and family policies in Europe (vol. 2 Problems and Issues in Comparative Perspective, pp. 419-490). Oxford, New York: Oxford University Press.

Lewis, J. (2009). Work-family balance, gender and policy. Cheltenham, UK: Edward Elgar.

Lohmann, P., Peter, F. H., Rostgaard, T., \& Spiess, C. K. (2009). Towards a framework for assessing family policies in the EU (OECD Social, Employment and Migration Working Papers, No. 88). Paris: OECD.

Mahon, R. (2010). After neo-liberalism: The OECD, The World Bank and the child. Global Social Policy, 10(2), 172-192.

Mätzke, M., \& Ostner, I. (2010). Introduction: Change and continuity in recent family policies. Journal of European Social Policy, 20(5), 387-398.

Millar, J., \& Warman, A. (1996). Family obligations in Europe. London: Family Policy Studies Centre.

Montanari, I. (2000). From family wage to marriage subsidy and child benefits: Controversy and consensus in the development of family policy. Journal of European Social Policy, 10(4), 307-333.

Moss, P. (2006). From a childcare to a pedagogical discourse. In J. Lewis (Ed.), Children, changing families and welfare states (pp. 154-172). Cheltenham, UK: Edward Elgar.

Papadopoulos, T., \& Roumpakis, A. (2019). Family as socio-economic actor in the political economy of welfare. In E. Heins, J. Rees, \& C. Needham (Eds.), Social policy review 31 analysis and debate in social policy, 2019 (pp. 243-266). Bristol, UK: Policy Press.

Saraceno, C. (2011). Family policies: concepts, goals and instruments. Carlo Alberto Notebooks, 230, 20.

Saraceno, C., \& Keck, W. (2010). Can we identify intergenerational policy regimes in Europe? European Societies, 10(5), 675-696.

Scheiwe, K., \& Willekens, H. (2009). Introduction: Path-dependencies and change in child-care and preschool institutions in Europe-Historical and institutional 
perspectives In K. Scheiwe \& H. Willekens (Eds.), Child care and preschool development in Europe (pp. 1-22). London: Palgrave Macmillan.

Spasova, S., Baeten, R., Coster, S., Ghailani, D., Pena-Casas, R., \& Vanhercke, B. (2018). Challenges in long-term care in Europe, a study of national policies 2018. Brussels: European Commission.

Therborn, G. (2004). Between sex and power: Family in the World, 1900-2000. London: Routledge.

Wennemo, I. (1994). Sharing the costs of children studies on the development of family support in the OECD. Stockholm: Swedish Institute for Social Research.

Williams, F. (2004). Rethinking families. London: Calouste Gulbenkian Foundation.

Open Access This chapter is licensed under the terms of the Creative Commons Attribution 4.0 International License (http://creativecommons.org/licenses/by/4.0/), which permits use, sharing, adaptation, distribution and reproduction in any medium or format, as long as you give appropriate credit to the original author(s) and the source, provide a link to the Creative Commons licence and indicate if changes were made.

The images or other third party material in this chapter are included in the chapter's Creative Commons licence, unless indicated otherwise in a credit line to the material. If material is not included in the chapter's Creative Commons licence and your intended use is not permitted by statutory regulation or exceeds the permitted use, you will need to obtain permission directly from the copyright holder.

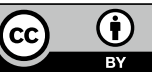

